\title{
Faktor-Faktor yang Mempengaruhi Adopsi Cloud oleh Instansi Pemerintah: Tinjauan Pustaka Sistematis
}

\author{
Factors Influencing Cloud Adoption by Government Agencies: Systematic \\ Literature Review
}

\author{
Betharia Wahyu Rizdawaty $^{1}$, Hindayati Mustafidah ${ }^{2 *}$ \\ 1,2 Teknik Informatika,Universitas Muhammadiyah Purwokerto \\ *corr-author: h.mustafidah@ump.ac.id
}

\begin{abstract}
ABSTRAK
Indonesia merupakan negara besar dengan jumlah instansi pemerintah yang sangat banyak (34 kementerian, 30 lembaga non kementerian, 34 Provinsi, dan 514 Kabupaten/Kota). Era revolusi industri 4.0 saat ini mendorong instansi pemerintah untuk terus meningkatkan pelayanan melalui pemanfaatan teknologi informasi. Pemanfaatan teknologi informasi di instansi pemerintah tidak sepenuhnya merata, bergantung pada kemampuan pembiayaan pengembanan teknologi informasi di masing-masing instansi. Skema On Premises yang saat ini masih digunakan oleh sebagian besar instansi membuat pembiayaan yang sangat besar (sumber daya manusia, perangkat keras, perangkat lunak, kelistrikan dan biaya komunikasi). Teknologi cloud computing atau komputasi awan sudah banyak digunakan di instansi-instansi pemerintah negara lain, akan tetapi penggunaan komputasi awan belum banyak diadopsi oleh instansi pemerintah di Indonesia walaupun teknologi ini bisa menjadi solusi bagi instansi yang memiliki pembiayaan dan sumber daya manusia terbatas untuk sektor teknologi informasinya. Studi ini bertujuan memberikan tinjauan literatur yang ada tentang faktor-faktor adopsi cloud oleh instansi pemerintah di beberapa negara sehingga pemerintah dapat mensosialisasikan dan menginternalisasi pemahaman keuntungan apa saja yang dapat diperoleh jika menggunakan komputasi awan. Studi ini menggunakan metode systematic literature review atau tinjauan pustaka sistematis dan membuat analisis sintesis berdasarkan model penelitian menggunakan checklist PRISMA. Hasil studi menunjukkan terdapat 8 (delapan) faktor yang menentukan keputusan adopsi cloud oleh instansi pemerintah di beberapa negara yaitu pengurangan biaya, fleksibilitas, redundansi dan keandalan, skalabilitas, kolaborasi, efisiensi, virtualitas, dan ketersediaan. Pemerintah dapat mensosialisasikan faktor pendukung tersebut kepada instansi-instansi pemerintah dan memperkuatnya lagi dengan pembuatan regulasi tentang pemanfaatan komputasi awan dan perlindungannya.
\end{abstract}

Kata-kata kunci: komputasi awan, instansi pemerintah, tinjauan pustaka sistematis, PRISMA

\begin{abstract}
Indonesia is a large country with a large number of government institutions (34 ministries, 30 non-ministerial institutions, 34 provinces, and 514 districts/cities). The era of the industrial revolution 4.0 currently encourages government institutions to continue to improve services through the use of information technology. Utilization of information technology in government institutions is not completely evenly distributed, depending on the ability to finance the development of information technology in each institutions. The
\end{abstract}


On Premises scheme which is currently still used by most institutions makes a very large amount of funding (human resources, hardware, software, electricity and communication costs). Cloud computing technology has been widely used in government institutions in other countries, but the use of cloud computing has not been widely adopted by government institutions in Indonesia, although this technology can be a solution for institutions that have limited funding and human resources for the information technology sector. . This study aims to provide a review of the existing literature on the factors of cloud adoption by government institutions in several countries so that the government can disseminate and internalize an understanding of what benefits can be obtained from using cloud computing. This study uses a systematic literature review method and makes a synthesis analysis based on the research model using the PRISMA checklist. The results of the study show that there are 8 (eight) factors that determine cloud adoption decisions by government agencies in several countries, namely cost reduction, flexibility, redundancy and reliability, scalability, collaboration, efficiency, virtuality, and availability. The government can socialize these supporting factors to government institutions and strengthen it again by making regulations on the use of cloud computing and its protection.

Keywords: cloud computing, government institutions, systematic literature review, PRISMA.

\section{PENDAHULUAN}

Peningkatan pelayanan publik instansi pemerintah merupakan salah satu program yang dicanangkan pada reformasi birokrasi yang dilakukan melalui pembangunan pemerintahan elektronik di mana layanan-layanan pemerintah yang semula banyak dilakukan secara manual, diubah menjadi layanan berbasis teknologi informasi. Instansi pemerintahan di Indonesia jumlahnya sangat banyak, pada tingkat daerah terdapat 416 kabupaten, 98 kota, 7.252 kecamatan, dan 83.820 desa (Kementrian Dalam Negeri, 2019). Pada tingkat pusat terdapat 34 kementerian (Peraturan Presiden, 2019) dan 30 lembaga non kementerian (Peraturan Presiden, 2015). Pembangunan pemerintahan elektronik berjalan tidak secepat yang diharapkan. Pemerintah elektronik yang dibangun sebagian besar on premises di mana jaringan, penyimpanan, peladen, sistem operasi, middleware, data, dan aplikasi secara fisik ada pada instansi. Untuk membuat dan menjaga keberlangsungan sistem pemerintahan berbasis elektronik tersebut, instansi harus memiliki sumber daya yang kuat, baik dari segi pembiayaan maupun dari segi kemampuan sumber daya manusia di bidang teknologi informasi. Instansi dengan kemampuan pendanaan yang kuat dan sumber daya manusia di bidang teknologi informasi yang mumpuni akan mampu mengembangkankan sistem pemerintahan berbasis elektronik dengan baik walaupun menimbulkan pembiayaan yang tinggi, sedangkan instansi dengan kekurangan dalam kemampuan pendanaan dan sumber daya manusia di bidang teknologi informasi, mengalami kesulitan untuk dapat membangun sistem pemerintahan berbasis elektronik yang baik. Pemerintahan cerdas memerlukan pemerintahan yang lincah dengan tingkat kolaborasi yang tinggi.

Komputasi awan adalah model untuk memungkinkan akses jaringan di mana-mana, nyaman, sesuai permintaan ke kumpulan layanan bersama (misalnya, jaringan, peladen, penyimpanan, aplikasi, dan layanan) yang dapat disediakan dan dirilis dengan cepat dengan upaya manajemen atau penyedia layanan minimal interaksi. Titik penting dalam perkembangan komputasi awan terjadi pada tahun 2006 ketika Amazon mengembangkan produk penyedia komputasi awan yaitu Amazon Web Service (AWS). Lima karakteristik esensial menurut NIST, yaitu: layanan mandiri terhadap permintaan, akses jaringan yang luas, pengumpulan sumber daya, elastisitas cepat, dan layanan terukur. 
Layanan awan dapat dikategorikan berdasarkan tiga model layanan sebagai berikut: Perangkat Lunak sebagai Layanan (SaaS), Platform sebagai Layanan (PaaS), dan Infrastruktur sebagai Layanan (IaaS). SaaS memungkinkan konsumen untuk menggunakan aplikasi penyedia layanan yang berjalan di infrastruktur awan. Konsumen dapat mengakses aplikasi menggunakan berbagai perangkat klien melalui antarmuka klien seperti browser web. Konsumen memiliki akses ke pengaturan konfigurasi aplikasi khusus pengguna yang terbatas dan tidak dapat mengelola atau mengontrol infrastruktur awan yang mendasarinya seperti jaringan, peladen, sistem operasi, atau penyimpanannya. Model komputasi awan PaaS memungkinkan konsumen untuk menyebarkan aplikasi yang dibuat atau diperoleh konsumen ke infrastruktur awan dengan bantuan bahasa pemrograman dan alat yang didukung penyedia. Sama seperti model SaaS, konsumen tidak mengelola atau mengontrol infrastruktur awan yang mendasarinya, tetapi dapat mengontrol aplikasi yang diterapkan dan mungkin konfigurasi lingkungan hosting aplikasi. IaaS menyediakan pemrosesan, penyimpanan, jaringan, dan sumber daya komputasi fundamental lainnya. Konsumen dapat menyebarkan dan menjalankan sistem operasi dan aplikasi. Seperti dua model lainnya, konsumen tidak dapat mengelola atau mengontrol infrastruktur awan yang mendasarinya tetapi memiliki kendali atas sistem operasi, penyimpanan, dan aplikasi yang diterapkan dan mungkin memiliki kontrol terbatas atas komponen jaringan tertentu, seperti firewall host.

Terdapat empat model awan, yaitu: publik; pribadi; masyarakat; dan hibrida. Awan publik memungkinkan infrastruktur awan yang tersedia untuk masyarakat umum. Infrastruktur dimiliki oleh organisasi yang menyediakan layanan awan. Dalam model awan pribadi, infrastruktur awan diterapkan hanya untuk satu organisasi. Organisasi itu sendiri dapat mengelola infrastruktur atau melakukan mengalihdayakan ke pihak ketiga, dan infrastruktur awawn mungkin ada di lokasi organisasi atau berbasis di luar lokasi. Awan komunitas menyebarkan infrastruktur awan ke beberapa organisasi secara bersamaan dan mendukung komunitas tertentu yang memiliki masalah serupa. Infrastruktur awan dapat dikelola oleh organisasi atau oleh pihak ketiga dan mungkin ada di lokasi organisasi atau berbasis di luar lokasi. Dalam model awan hibrida, infrastruktur awan terdiri dari dua atau lebih awan (privat, komunitas atau publik) yang tetap merupakan entitas unik tetapi terikat bersama oleh teknologi standar atau kepemilikan yang memungkinkan portabilitas data dan aplikasi (Ali, Soar and Yong, 2016).

Awan pemerintahan elektronik (e-Gov) berarti memanfaatkan TIK untuk menemukan kembali proses bisnis dan memberikan layanan pemerintah untuk mengubah hubungan dengan warga negara (G2C), bisnis (G2B), karyawan (G2E), dan badan pemerintah lainnya $(\mathrm{G} 2 \mathrm{G})$. Mengadopsi e-Gov secara luas di sektor publik memberikan manfaat yang tak terbantahkan bagi pemerintah dan publik, misalnya, meningkatkan efisiensi, memfasilitasi transformasi fungsi, mempromosikan transparansi, dan menyediakan layanan berkualitas tinggi. Namun, dengan pemanfaatan lebih lanjut dari sistem e-Gov, tantangan yang lebih teknis, organisasi dan ekonomi, misalnya, penggunaan rendah dan investasi tinggi, biaya yang terus meningkat, sistem duplikat dan kesenjangan digital, meningkatnya permintaan warga, dan kesulitan kolaborasi, telah muncul 'Paradoks e-Gov' sangat membatasi pengembangan e-Gov dan pembangunan pemerintahan yang cerdas, dan memaksa pemerintah untuk berinovasi dan mengikuti inovasi TI terkini. Komputasi awan, inti dari revolusi TI generasi berikutnya, telah mendapatkan popularitas baru-baru ini, dan telah diadopsi secara luas oleh perusahaan dan individu, misalnya, penyimpanan awan, awan perusahaan dan awan mobile.

Komputasi awan juga dapat sangat mengubah lingkungan teknologi konstruksi eGov, dan memberikan kesempatan untuk memecahkan tantangan. Menyadari keniscayaan awan dalam pekerjaan TI pemerintah, banyak negara, tidak hanya negara maju (AS, Inggris, Singapura, UE, dan Jepang), tetapi juga negara berkembang (Thailand dan 
Malaysia), telah meluncurkan gerakan awanisasi untuk efisiensi yang lebih tinggi. Meskipun strategi awan e-Gov dipandu oleh kebijakan nasional, dalam praktiknya mengalami banyak hambatan. Jika sektor publik tidak mempersiapkan adopsi awan e-Gov (yaitu adopsi tidak mencapai tingkat yang signifikan), investasi platform awan yang didirikan oleh hulu akan sia-sia dan tidak memiliki manfaat yang signifikan (Liang et al., 2017).

Dari uraian di atas dapat dilihat bahwa pembangunan e-Gov Indonesia masih memiliki kendala yang berhubungan dengan pembiayaan pengembangan sistem pemerintahan berbasis elektronik dan sumber daya manusia di bidang teknologi informasi yang mampu untuk mengembangkan dan mengelola sistem pemerintahan berbasis elektroik. adopsi awan bisa membantu pemerintah dalam melakukan percepatan terhadap pembangunan pemerintah elektronik (e-Gov). Adopsi awan sendiri dipengaruhi oleh berbagai faktor, sehingga diperlukan studi faktor-faktor apa saja yang membuat pemerintah-pemenrintah di negara lain memutuskan untuk mengadopsi awan sebagai bagian pengembangan e-Gov mereka.

Penelitian ini dibatasi pada pembahasan faktor-faktor yang mendukung sebuah instansi pemerintah untuk melakukan adopsi komputasi awan dengan melakukan kajian pustaka sistematis pada jurnal-jurnal yang terbit maksimal 10 tahun ke belakang.

Tujuan penelitian adalah untuk mendapatkan faktor-faktor yang mendukung instansi pemerintah mengadopsi komputasi awan. Diharapkan hasil penelitian ini dapat menjadi salah satu bahan pertimbangan yang digunakan pemerintah atau praktisi teknologi informasi dalam upaya percepatan pembangunan e-Gov di Indonesia dengan memanfaatkan teknologi komputasi awan.

\section{METODE PENELITIAN}

Alur metode penelitian berupa definisi permasalahan, pengumpulan data, pengolahan data, dan pengambilan kesimpulan. Kerangka penelitian datap dilihat pada Gambar 1.

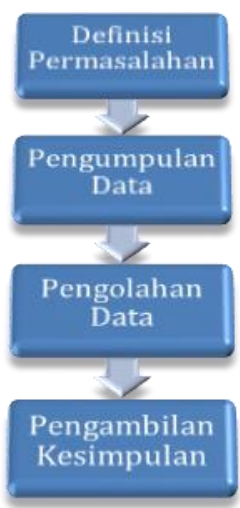

\section{Gambar 1. Kerangka penelitian}

Berdasarkan Gambar 1, tahapan penelitian terdiri dari:

\section{Definisi Permasalahan}

Definisi permasalahan dilakukan dengan mempelajari dan menganalisis pengembangan sistem pemerintah berbasis elektronik di Indonesia dibandingkan dengan pengembangan sistem pemerintahan berbasis elektronik di beberapa negara lainnya sehingga didapatkan rumusan permasalahan yang dihadapi. Pada tahapan ini ditentukan 
tujuan, ruang lingkup penelitian, identifikasi kemungkinan penyelesaian masalah, dan menentukan metode dalam pengambilan keputusan.

\section{Pengumpulan Data}

Data yang dikumpulkan pada penelitian ini adalah data dari jurnal internasional. Jurnal-jurnal tersebut didapatkan dari pencarian di internet pada basis data Science Direct dan Scopus.

\section{Pengolahan Data}

Data yang diperoleh diolah melalui empat tahapan, yaitu:

Tahap 1: Pencarian Otomatis Elektronik berdasarkan kata kunci, menggunakan basis data ilmiah

Tahap 2: Pemilihan berdasarkan judul penelitian

Tahap 3: Pemilihan berdasarkan abstrak penelitian

Tahap 4: Pemilihan berdasarkan bukti empiris dari penelitian

\section{Pengambilan Kesimpulan}

Proses pengambilan keputusan dilakukan dengan ekstraksi dan sintesis data dengan membaca teks lengkap setiap artikel dengan cermat serta melakukan rekap ekstrasi dan sintesis pada sebuah tabel. Data yang diekstrak adalah: ID penelitian, referensi bibliografi, tipe penelitian, konteks adopsi awan, teori yang digunakan, dan konteks lain yang berhubungan. Sintesis dilakukan dengan merangkum temuan utama pada artikel yang telah lolos pada tahap pengolahan data.

\section{HASIL DAN PEMBAHASAN}

\section{Pengumpulan dan Pengolahan Data}

Pencarian artikel menggunakan kriteria kata kunci pada basis data Science Direct dan Scopus. Lima kata kunci (komputasi awan, adopsi awan, faktor keberhasilan awan, eGovernment, faktor yang mempengaruhi adopsi awan) digunakan untuk menemukan artikel yang relevan di basis data tersebut. Artikel yang dipilih adalah artikel yang berupa teks lengkap dalam ranah komputasi awan dengan waktu penerbitan dalam rentang waktu sepuluh tahun (Gambar 2).

Pada tahap pertama diidentifikasi 52 artikel dari basis data ilmiah. Semua artikel yang ditemukan masuk ke tahap kedua. Pada tahap kedua setiap judul artikel dibaca dan artikel dengan judul yang memiliki sedikit kesamaan dengan kriteria pencarian dieliminasi. 11 artikel dieliminasi dan 41 diikutsertakan ke tahap ketiga.

Pada tahap ketiga, abstrak makalah dan teks lengkap untuk menilai relevansinya. Relevansi dinilai dari tujuan penelitian masing-masing artikel, domain konteks, temuan kontribusi, dan konteks penting lainnya. Artikel yang tidak sesuai dengan kriteria ini dieliminasi dari penelitian, 14 artikel dieliminasi karena artikel tersebut tidak membahas komputasi awan pada instansi pemerintah, 27 artikel dikirim ke tahap terakhir.

Pada tahap terakhir, kriteria seleksi diterapkan dengan mempertimbangkan teks lengkap, 12 artikel dieliminasi karena teks tidak lengkap dan menyisakan 15 artikel yang dimasukkan ke dalam tahapan ekstrasi dan sintesis. 


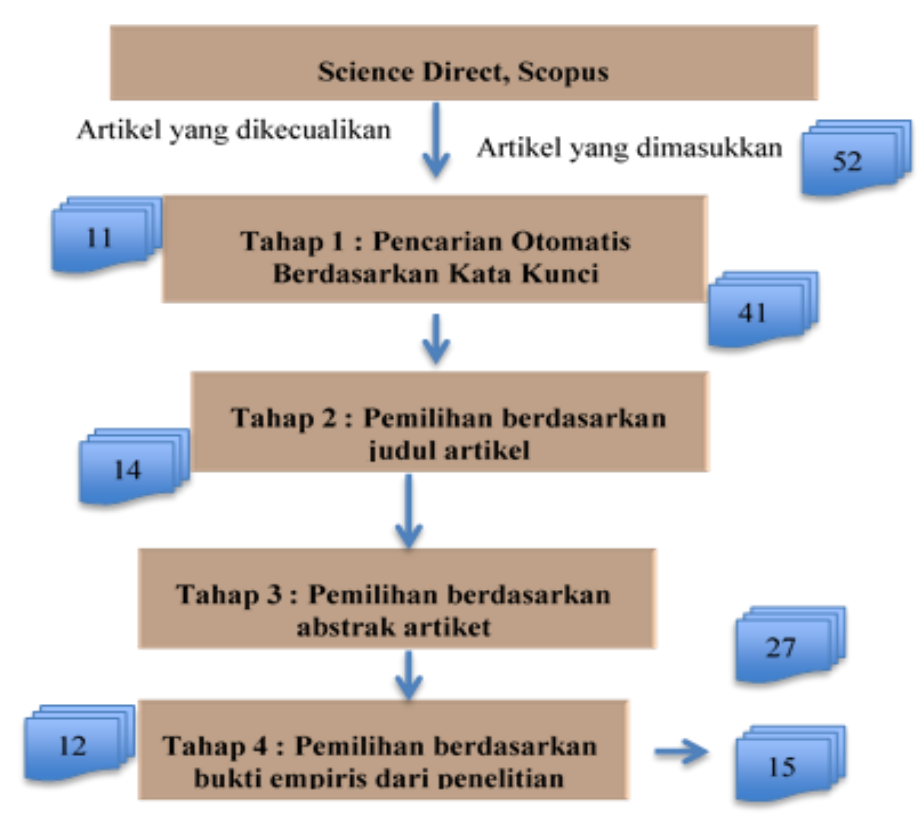

Gambar 2. Hasil proses pemilihan data

Pengolahan data artikel juga menghasilkan sebaran pada domain apa saja bisa ditemui topik terkait komputasi awan instansi pemerintah serta sebaran artikel per tahun penerbitan (Tabel 1).

Tabel 1. Sebaran artikel

\begin{tabular}{clc}
\hline \multicolumn{1}{c}{ Karakteristik } & \multicolumn{1}{c}{ Sebaran Domain } & Jumlah \\
\hline Jurnal & Computer Science & 6 \\
& Government Information Quaterly & 2 \\
& Information Security & 1 \\
& Network Computer Applications & 1 \\
& System and Software & 1 \\
& Telematics and Informatics & 1 \\
& Information Management & 1 \\
& Information and Software Technology & 1 \\
& Computers in Human Behaviour & 1 \\
Tahun Penerbitan & 2010 & 1 \\
& 2013 & 1 \\
& 2014 & 1 \\
& 2015 & 2 \\
& 2016 & 5 \\
& 2017 & 5 \\
\hline
\end{tabular}

Pada Tabel 1 terlihat bahwa sebagian besar penelitian didapatkan dari Jurnal Ilmu Komputer (6), disusul Government Information Quaterly (2), Jurnal lainnya memiliki jumlah yang sama yaitu 1 .

\section{Ekstraksi Data}

Hasil dari pendalaman setiap artikel, data diekstraksi dan disintesis dengan tujuan untuk dimasukkan dalam analisis untuk berbagai masalah adopsi awan seperti tujuan, model, teori menggunakan kontribusi temuan utama. Informasi ini digunakan untuk mensistematisasikan, menyusun, dan mensintesis teori. 
Ekstrasi informasi dilakukan untuk menemukan masalah utama dan menilai kualitas artikel agar artikel yang dipilih memenuhi kriteria sebagai berikut (Tabel 2):

a. topik yang dibahas dalam artikel sesuai dengan topik penelitian;

b. konteks penelitian dijelaskan dalam artikel;

c. metode pengumpulan data dijelaskan dalam artikel; dan

d. analisis datanya akurat dan dijelaskan dengan jelas.

Tabel 2. Data yang diekstraksi

\begin{tabular}{ll}
\hline \multicolumn{1}{c}{ Data yang Diekstrak } & \multicolumn{1}{c}{ Deskripsi } \\
\hline ID penelitian & Identitas unik dari setiap penelitian \\
Referensi bibliografi & Penulis, judul, tahun penerbitan, dan sumber \\
& publikasi \\
Tipe penelitian & Jurnal dan prosiding \\
Konteks adopsi awan & Deskripsi domain penelitian, missal: e- \\
& Government, faktor kesuksesan \\
Teori yang digunakan dalam model yang & SaaS, PaaS, and IaaS \\
diusulkan & \\
Konteks lain & Dampak, hambatan \\
\hline
\end{tabular}

Pada Tabel 2 dijelaskan bahwa data yang diekstrak adalah identitas unik dari penelitian, penulis, judul, tahun penerbitan, sumber publikasi, tipe penelitian (jurnal dan prosiding), deskripsi domain penelitian, teori yang digunakan dan konteks lain yang dianggap relevan seperti dampak dan hambatan.

Hasil ekstrasi penelitian dapat dilihat pada Tabel 3. Hasil ekstrasi ini menampilkan perspektif teoretis, variabel bebas, dan temuan utama pada masing-masing penelitian.

Tabel 3. Hasil ekstrasi artikel

\begin{tabular}{|c|c|c|}
\hline Perspektif Teoretis & Variabel Bebas & Temuan Utama \\
\hline $\begin{array}{l}\text { U.S. National Institute } \\
\text { of Standards and } \\
\text { Technology/NIST } \\
\text { (Ali, Soar and Yong, } \\
\text { 2016) }\end{array}$ & $\begin{array}{l}\text { Partisipasi dari } \\
\text { Dewan Pemerintah } \\
\text { Daerah, Pertumbuhan } \\
\text { dalam adopsi } \\
\text { komputasi awan }\end{array}$ & $\begin{array}{l}\text { Tantangan dan isu yang mempengaruhi } \\
\text { adopsi atau komputasi awan adalah: jaringan } \\
\text { yang efektif, keamanan dan kontrol terhadap } \\
\text { kehilangan data, lokasi penyimpanan data, } \\
\text { biaya, ketersediaan penyedia yang berbeda, } \\
\text { cadangan data, privasi, integrasi, pembuat } \\
\text { kebijakan, kurangnya pemahaman yang } \\
\text { nyata tentang awan }\end{array}$ \\
\hline $\begin{array}{l}\text { Adopsi Komputasi } \\
\text { Awan (Liang et al., } \\
\text { 2017) } \\
\text { National Institute of } \\
\text { Standards and } \\
\text { Technology (Singh, } \\
\text { Jeong and Park, 2016) }\end{array}$ & $\begin{array}{l}\text { Model adopsi, faktor } \\
\text { adopsi awan e-Gov, } \\
\text { adopsi e-Gov } \\
\text { keamanan, perjanjian } \\
\text { tingkat layanan } \\
\text { (SLA), metadata, } \\
\text { komputasi } \\
\text { berkelompok }\end{array}$ & $\begin{array}{l}\text { Lima kategori utama: kepercayaan terhadap } \\
\text { awan, teknologi, dukungan penyedia awan, } \\
\text { kesiapan organisasi, dan stimulus lingkungan } \\
\text { Keamanan adalah tantangan utama dalam } \\
\text { adopsi awan }\end{array}$ \\
\hline $\begin{array}{l}\text { Structural Equation } \\
\text { Modeling (SEM) } \\
\text { (Phaphoom et al., } \\
\text { 2015) }\end{array}$ & $\begin{array}{l}\text { Privasi data dan } \\
\text { legalitas, portabilitas, } \\
\text { dan kompleksitas } \\
\text { migrasi }\end{array}$ & $\begin{array}{l}\text { Hambatan teknis utama menghasilkan } \\
\text { akurasi sekitar } 70 \% \text { untuk memprediksi } \\
\text { keputusan adopsi awan di perusahaan }\end{array}$ \\
\hline
\end{tabular}




\begin{tabular}{|c|c|c|}
\hline Perspektif Teoretis & Variabel Bebas & Temuan Utama \\
\hline $\begin{array}{l}\text { Faktor Penentu } \\
\text { Kesuksesan Migrasi } \\
\text { awan (Alharthi et al., } \\
\text { 2017) }\end{array}$ & $\begin{array}{l}\text { Berbasis } \\
\text { pengetahuan, } \\
\text { Pelatihan TI, } \\
\text { Dukungan } \\
\text { Manajemen }\end{array}$ & $\begin{array}{l}\text { Faktor penentu kesuksesan untuk: } \\
\text { - migrasi awan } \\
\text { - Teknologi (Keandalan, Keamanan, } \\
\text { Interoperabilitas) } \\
\text { - Organisasi (Persyaratan SLA, Rencana } \\
\text { Migrasi, Kepatuhan dengan peraturan) }\end{array}$ \\
\hline $\begin{array}{l}\text { TOE-Framework dan } \\
\text { Model HOT-fit (Lian, } \\
\text { Yen and Wang, 2014) }\end{array}$ & SaaS, PaaS, IaaS & $\begin{array}{l}\text { Keputusan adopsi komputasi awan } \\
\text { mencakup empat dimensi: Teknologi, } \\
\text { Manusia, Organisasi, dan Lingkungan }\end{array}$ \\
\hline $\begin{array}{l}\text { Hambatan dan Faktor } \\
\text { Kesuksesan Tata } \\
\text { Kelola awan Data (Al- } \\
\text { Ruithe and Benkhelifa, } \\
\text { 2017) }\end{array}$ & $\begin{array}{l}\text { Kerahasiaan, } \\
\text { integritas, kualitas, } \\
\text { dan ketersediaan data } \\
\text { pelanggan }\end{array}$ & $\begin{array}{l}\text { Faktor hambatan paling umum yang dapat } \\
\text { memengaruhi penerapan tata kelola data } \\
\text { awan adalah: organisasi, pengetahuan, } \\
\text { lingkungan, budaya, manusia, teknologi, } \\
\text { fungsional, dan keuangan. } \\
\text { Faktor penentu kesuksesan tata kelola data } \\
\text { awan: Perencanaan strategis, organisasi, } \\
\text { teknologi, lingkungan, keterlibatan } \\
\text { pemangku kepentingan, pemantauan dan } \\
\text { berkelanjutan, penyelarasan strategis, } \\
\text { manajemen strategis }\end{array}$ \\
\hline
\end{tabular}

Komputasi awan dan pemerintahan elektronik (Elbadawi, 2011)

Model Penilaian Risiko Keamanan (Jouini and Rabai, 2016)

Paradigma pemerintah elektronik menggunakan infrastruktur awan (Dash and Pani, 2016)

Keamanan Informasi komputasi awan (Rebollo et al., 2015)

Risiko - berwujud dan tak berwujud dikaitkan dengan penggunaan komputas awan (Paquette, Jaeger and Wilson, 2010)
Layanan publik, layanan awan

Sumber daya komputasi yang dapat dikonfigurasi, proses manajemen risiko organisasi

fasilitas tata kelola elektronik, model layanan komputasi awan

Struktur tata kelola keamanan informasi, keamanan awan

Berbagi informasi, pemrosesan informasi, kategori untuk mengidentifikasi kemungkinan risiko
Mempertahankan kepemimpinan yang kuat di tingkat daerah, memungkinkan inovator lokal dan mensponsori keterbukaan di sektor publik

\section{Mean Failure Cost Extension Model}

(MFCE) menganggap klasifikasi ancaman sebagai dasar dari model klasifikasi ancaman dan memungkinkan pemberian solusi ancaman berdasarkan kelas, model ini tidak mewakili biaya menurut dimensi atau perspektif ancaman keamanan

layanan pemerintah elektronik yang lebih baik dapat tersedia bagi pengguna jika layanan tersebut tersedia melalui infrastruktur awan

ISGcloud menggunakan kerangka kerja berorientasi proses yang memandu pengguna melalui langkah-langkah mengembangkan struktur tata kelola keamanan seputar penerapan awan dan didasarkan pada siklus hidup layanan awan

Jenis risiko: Risiko berwujud / diketahui (Akses, Ketersediaan, infrastruktur, integritas) dan Risiko Tak Berwujud / Tidak Diketahui:Akses dan penggunaan awan, keandalan awan, layanan yang berkelanjutan, keamanan akses, mekanisme keamanan, kerahasiaan dan privasi data, pelestarian informasi dan dokumen, 


\begin{tabular}{|c|c|c|}
\hline Perspektif Teoretis & Variabel Bebas & Temuan Utama \\
\hline & & $\begin{array}{l}\text { penanggungjawab jika terjadi masalah, } \\
\text { perlindungan hak kekayaan intelektual, } \\
\text { portabilitas data dan sumber daya antara } \\
\text { berbagai bagian awan, kapasitas yang akan } \\
\text { diaudit, dan lokasi yuridiksi hukum. }\end{array}$ \\
\hline $\begin{array}{l}\text { Model Sukses Sistem } \\
\text { Informasi (Azeemi, } \\
\text { Lewis and Tryfonas, } \\
\text { 2013) }\end{array}$ & $\begin{array}{l}\text { Virtualisasi dan } \\
\text { komputasi grid, } \\
\text { kualitas informasi, } \\
\text { kualitas layanan }\end{array}$ & $\begin{array}{l}\text { pandangan holistik yang menghargai } \\
\text { konteks dan memberikan fokus pada sistem } \\
\text { informasi dapat membantu konsumen dan } \\
\text { penyedia untuk membuat keputusan yang } \\
\text { lebih tepat saat memigrasi sistem informasi } \\
\text { ke awan }\end{array}$ \\
\hline $\begin{array}{l}\text { Model Jaringan Saraf } \\
\text { (Sharma et al., 2016) }\end{array}$ & $\begin{array}{l}\text { Penggunaan } \\
\text { komputasi awan, } \\
\text { profesional TI, } \\
\text { Tingkat pendidikan }\end{array}$ & $\begin{array}{l}\text { faktor-faktor kesempatan kerja, kepercayaan } \\
\text { terhadap kemampuan diri berhasil } \\
\text { diintegrasikan ke dalam Technology } \\
\text { Acceptance Model (TAM) dan faktor-faktor } \\
\text { tersebut dianggap penting dalam } \\
\text { mempengaruhi adopsi layanan komputasi } \\
\text { awan }\end{array}$ \\
\hline $\begin{array}{l}\text { Keamanan pada awan } \\
\text { untuk segalanya dan } \\
\text { internet untuk } \\
\text { segalanya (Sahmim } \\
\text { and Gharsellaoui, } \\
\text { 2017) }\end{array}$ & $\begin{array}{l}\text { awan untuk segalanya } \\
\text { dan internet untuk } \\
\text { segalanya, } \\
\text { manajemen keamanan }\end{array}$ & $\begin{array}{l}\text { Untuk mengamankan komputasi, isu privasi } \\
\text { dan keamanan dapat berpengaruh pada } \\
\text { efektivitas sistem }\end{array}$ \\
\hline
\end{tabular}

\section{Sintesis data}

Setelah ekstrasi data dilakukan maka dilakukan sintesis terhadap masing-masing penelitian dengan pendekatan agregasi meta di mana jawaban penelitian dihasilkan dari rangkuman berbagai hasil penelitian. Hasil sintesis adalah sebagai berikut:

a. Pengurangan Biaya

Penggunaan komputasi awan akan menekan biaya pengelolaan teknologi informasi. Biaya-biaya tersebut diantaranya biaya: perangkat keras, perangkat lunak, lisensi, kelistrikan, perawatan, dan jaringan komunikasi. Pengurangan biaya ini akan menyebabkan instansi pemerintah dengan pendanaan kuat pada bidang teknologi informasi dapat mengalihkan biaya untuk membiayai kegiatan instansi lainnya, sedangkan untuk instansi pemerintah dengan pendanaan yang kurang kuat akan mampu untuk memiliki fasilitas teknologi informasi dengan biaya yang dapat dijangkau.

\section{b. Fleksibilitas}

Layanan komputasi awan menawarkan fleksibilitas untuk membangun fasilitas teknologi informasi disesuaikan dengan skala infrastruktur instansinya tanpa harus terbebani biaya investasi awal.

c. Redundansi dan Keandalan

Redundansi (atau duplikasi bawaan sistem, data, peralatan, dan komponen lainnya) pada layanan awan dapat menyelamatkan instansi dari kehilangan data.

\section{d. Skalabiltas}

Komputasi awan memungkinkan untuk menambah atau mengurangi sumber daya teknologi informasi sesuai dengan kebutuhan. 


\section{e. Kolaborasi}

Setiap data yang tersimpan dalam awan dapat diakses oleh siapapun yang memiliki hak akses kapanpun dan dimanapun. Hal ini sangat cocok diterapkan pada saat pandemi seperti saat ini di mana hampir sebagian besar pegawai pemerintah melaksanakan tugasnya dari rumah. Kolaborasi ini juga dapat membantu mengakselerasi pembangunan pemerintah cerdas di mana antar instansi pemerintah dapat menggunakan data dan informasi bersamaan sesuai dengan kewenangannya.

\section{f. Efisiensi}

Penggunaan komputasi awan meningkatkan efisiensi mulai dari efisiensi biaya, efisiensi tempat (tidak lagi memerlukan tempat untuk membangun pusat data), dan efisiensi sumber daya manusia (tidak lagi memerlukan sumber daya manusia untuk mengelola pusat data).

\section{g. Virtualisasi}

Virtualisasi memungkinkan penghematan sumber daya sesuai kebutuhan, mengurangi jumlah peladen fisik, meningkatkan waktu aktif peladen, dan memudahkan manajemen pembuatan data cadangan atau mengembalikan data ke tempat semula.

h. Ketersediaan

Tingkat ketersediaan layanan yang tinggi pada komputasi awan juga menjadi faktor pendorong instansi dalam melakukan adopsi awan.

\section{KESIMPULAN}

Dari hasil penelitian didapatkan delapan faktor pendorong instansi pemerintah melakukan adopsi terhadap awan, yaitu: pengurangan biaya, fleksibilitas, redundansi dan keandalan, skalabilitas, kolaborasi, efisiensi, virtualisasi, dan ketersediaan. Kedelapan faktor tersebut harus disosialisasikan dan diinternalisasikan kepada instansi-instansi pemerintah untuk mendorong mereka mulai memanfaatkan teknologi komputasi awan. Dalam penelitian ditemukan juga tantangan signifikan yang dihadapi dalam adopsi awan/komputasi awan, yaitu isu keamanan. Banyak instansi yang meragukan keamanan data yang disimpan di awan, mereka takut data yang tersimpan di awan rentan pencurian, penyalahgunaan atau bahkan sulit didapatkan kembali ketika kerja sama dengan penyedia awan berakhir. Tantangan ini menyebabkan selain sosialisasi dan internalisasi delapan faktor pendorong, dibutuhkan juga regulasi pemerintah dalam pengelolaan dan pengamanan awan serta manajemen risiko dalam pemanfaatan awan. Hasil penelitian ini diharapkan dapat menjadi salah satu bahan pertimbangan yang digunakan pemerintah atau praktisi teknologi informasi dalam upaya percepatan pembangunan pemerintah cerdas di Indonesia dengan memanfaatkan teknologi komputasi awan.

\section{DAFTAR PUSTAKA}

Al-Ruithe, M. and Benkhelifa, E. (2017) 'Analysis and classification of barriers and critical success factors for implementing a cloud data governance strategy', Procedia computer science, 113 , pp. 223-232.

Alharthi, A. et al. (2017) 'An exploratory study for investigating the critical success factors for cloud migration in the Saudi Arabian higher education context', Telematics and Informatics, 34(2), pp. 664-678.

Ali, O., Soar, J. and Yong, J. (2016) 'An investigation of the challenges and issues influencing the adoption of cloud computing in Australian regional municipal governments', Journal of Information Security and Applications, 27, pp. 19-34. 
Azeemi, I. K., Lewis, M. and Tryfonas, T. (2013) 'Migrating to the cloud: Lessons and limitations of 'traditional'IS success models', Procedia Computer Science, 16, pp. 737-746.

Dash, S. and Pani, S. K. (2016) 'E-Governance paradigm using cloud infrastructure: Benefits and challenges', Procedia Computer Science, 85, pp. 843-855.

Elbadawi, I. (2011) 'Cloud computing for e-government in UAE: opportunities, challenges and service models', in Proceedings of the 5th International Conference on Theory and Practice of Electronic Governance, pp. 387-388.

Jouini, M. and Rabai, L. B. A. (2016) 'Comparative study of information security risk assessment models for cloud computing systems', Procedia Computer Science, 83, pp. 1084-1089.

Kementrian Dalam Negeri (2019) Peraturan Kementrian Dalam Negeri No.77 Tahun 2019 Tentang Kode dan Data Wilayah Administrasi Pemerintahan.

Lian, J.-W., Yen, D. C. and Wang, Y.-T. (2014) 'An exploratory study to understand the critical factors affecting the decision to adopt cloud computing in Taiwan hospital', International Journal of Information Management, 34(1), pp. 28-36.

Liang, Y. et al. (2017) 'Exploring the determinant and influence mechanism of eGovernment cloud adoption in government agencies in China', Government information quarterly, 34(3), pp. 481-495.

Paquette, S., Jaeger, P. T. and Wilson, S. C. (2010) 'Identifying the security risks associated with governmental use of cloud computing', Government information quarterly, 27(3), pp. 245-253.

Peraturan Presiden (2015) Peraturan Presiden Nomor 145 Tahun 2015 tentang Perubahan Kedelapan atas Keputusan Presiden Nomor 103 Tahun 2001 tentang Kedudukan, Tugas, Fungsi, Kewenangan, Susunan Organisasi, dan Tata Kerja Lembaga Pemerintah Non Kementerian.

Peraturan Presiden (2019) Peraturan Presiden Nomor 67 Tahun 2019 tentang Penataan Tugas dan Fungsi Kementerian Negara Kabinet Indonesia Maju Periode Tahun 2019-2024.

Phaphoom, N. et al. (2015) 'A survey study on major technical barriers affecting the decision to adopt cloud services', Journal of Systems and Software, 103, pp. 167181.

Rebollo, O. et al. (2015) 'Empirical evaluation of a cloud computing information security governance framework', Information and Software Technology, 58, pp. 44-57.

Sahmim, S. and Gharsellaoui, H. (2017) 'Privacy and security in internet-based computing: cloud computing, internet of things, cloud of things: a review', Procedia computer science, 112, pp. 1516-1522.

Sharma, S. K. et al. (2016) 'Predicting motivators of cloud computing adoption: A developing country perspective', Computers in Human Behavior, 62, pp. 61-69.

Singh, S., Jeong, Y.-S. and Park, J. H. (2016) 'A survey on cloud computing security: Issues, threats, and solutions', Journal of Network and Computer Applications, 75, pp. 200-222. 